ISSN (print) $0867-2008$ / ISSN (online) 2391-7512

DOI: http://dx.doi.org/10.12775/OM.2021.011

Nicholas W. Youmans*

Forschungsstelle Deutscher Orden

Oswald-Külpe-Weg 74

D-97074 Würzburg

Germany

nyoumans@gmail.com

\title{
BETWEEN COMMEMORATION AND LIVING MEMORY: SYMBOLIC ACTS OF THE TEUTONIC KNIGHTS IN LIGHT OF CULTURAL THEORY
}

\section{KEYWORDS}

history; the Middle Ages; military orders; Teutonic Order; rituals; cultural memory; estate; collective identity

\begin{abstract}
The present article investigates the function of ritual acts as a form of communication vis-à-vis cultural meaning in the life of the Teutonic Knights. As a condensed form of communal expression, rituals exhibit an acute potential to render present collective identity and shape the lives of the communities that practice them. Such potential is manifest in the institutional arrangement of the Teutonic Order in various forms with particular reference to their dual standing in society, insofar as they drew upon the societal models of the oratores and the bellatores. Particularly relevant to the current study, considerations of cultural historian and social analyst Jan Assmann regarding symbolic acts and collective living memory assist in creating the theoretical framework for the study's deliberations. With Assmann's insights in mind, ritual is understood as a communicative vector of cultural meaning - so to speak - of living memory. The analysis then turns to an examination of select representative examples from diverse scenarios in the existence of the Teutonic Knights, thereby taking into account internal, public, and participatory contexts of symbolic moments. The study thus explores how, while rituals can commemorate memorialised events from the past, they are also able to enact the living memory of a collective entity, ultimately claiming that the examined symbolic acts exhibited both communicative and transformative potential.
\end{abstract}

*ORCID: https://orcid.org/0000-0003-0934-3328 
I $\mathrm{n}$ a highly programmatic phrase, the vernacular adaptation of Peter of Dusburg's Chronicon terrae Prussiae uttered the following words, describing the life of the brothers at Christburg and underscoring the dual societal estate of the Teutonic Knights and the principles and ideals that informed and shaped their collective identity: $s \hat{i} \sin z u$ clôstremunche gût und hân zu velde rittirs mût. ${ }^{.}$The convent castle at Christburg - among the first of its kind in Prussia - was inhabited by brothers told to be godly and of commendable abstinence, who zealously followed the rule, and who were also capable fighters in battle, so that one could rightly claim that - as the quotable phrase implies - they were monastic in their way of living in the castle convent; in matters regarding their existence outside of its walls, however, they led a noble life of valour and chivalry. Such an indication of collective self-understanding is a single instance pertaining to a broader trend on the part of the Teutonic Order to establish a dual model of living on an institutional level - in other words, to configure and represent the military-religious order by referring to and embodying both monastic and courtly-noble ideals.

As a corporate entity that belonged to the estate of the "praying" (oratores) as well as that of the "fighting" (bellatores) ${ }^{2}$ - or at minimum that drew from both cultural spheres -, the Teutonic Order constituted a hybrid cultural amalgam comprising a symbiosis of the monastic and the courtly-noble. ${ }^{3}$ The members of

I "Di Kronike von Pruzinlant des Nicolaus von Jeroschin," ed. Ernst Strehlke, in Scriptores rerum Prussicarum, vol. I, eds. Theodor Hirsch, Max Toeppen, and Erich Strehlke (Leipzig: S. Hirzel, I 85 I), 404 v. 887 I.

2 The estate system in its medieval understanding and various forms of expression are well-founded points of interest in the literature. See: Ordnung und Distinktion-Praktiken sozialer Repräsentation in der ständischen Gesellschaft, eds. Marian Füssel and Thomas Weller (Münster: Rhema, 2005); Otto G. Oexle, "Die funktionale Dreiteilung als Deutungsschema der sozialen Wirklichkeit in der ständischen Gesellschaft des Mittelalters," in Ständische Gesellschaft und soziale Mobilität, ed. Winfried Schulze (Munich: De Gruyter, I988), I9-5 I; Otto G. Oexle, "'Die Statik ist ein Grundzug des mittelalterlichen Bewusstseins.' Die Wahrnehmung sozialen Wandels im Denken des Mittelalters und das Problem ihrer Deutung," in Sozialer Wandel im Mittelalter. Wahrnehmungsformen, Erklärungsmuster, Regelungsmechanismen, eds. Jürgen Miethke and Klaus Schreiner (Sigmaringen: Jan Thorbecke Verlag, I 994), 45-70.

3 On the dual status of the military-religious orders and their cultural spheres as knight-monks with emphasis on the Teutonic Knights, see: Mary Fischer, "Di himels rote:" The Idea of Christian Chivalry in the Chronicles of the Teutonic Order (Göppingen: Kümmerle, I99I); Kristjan Toomaspoeg, "La spiritualité des ordres religieux-militaires du Moyen Âge: l'état de la recherche," in Cister e as ordens militares na idade média. Guerra, igreja e vida religiosa, eds. José Albuquerque Carreiras and Carlos de Ayala Martínez Cister (Tomar: Associação portuguesa de Cister., 20 I 5), 23-45; Die Spiritualität der Ritterorden im Mittelalter, ed. Zenon H. Nowak (Toruń: Wydawnictwo Uniwersytetu Mikołaja Kopernika, I993); Michael Neecke, Literarische Strategien narrativer Identitätsbildung: eine Untersuchung der frühen Chroniken des Deutschen Ordens (Frankfurt: Peter Lang, 2008); Edith Feistner, Krieg im Visier: Bibelepik und Chronistik 
this mixed institution ranged from priest and knight brothers to oblati and in certain circumstances also women, all of whom arranged themselves in varied fashion according to this dual model of life. ${ }^{4}$ In perhaps no other sphere of communal existence is such a dynamic more evident than in that of symbolics acts and in particular rituals. Studies outlining other identity-forming phenomena of the military-religious orders more broadly and the Teutonic Knights in particular have become more plentiful in recent years, beginning with their textual output, especially with regard for chronicles and biblical epics and the heroic figures depicted within them. 5 Such studies have been well-founded and satisfactorily executed, but the ever-changing content of table readings as well as their uncertain standing within the various communities raises questions concerning the presence and impact of these sources in a day-to-day context. Another focal point regarding the identity of the Teutonic Knights has been an architectural one, ${ }^{6}$ thereby treating the layout of their convent castles and in particular the Grand Master's residence at

im Deutschen Orden als Modell korporativer Identitätsbildung (Berlin: De Gruyter, 2007); and Arno Mentzel-Reuters, "Der Deutsche Orden als geistlicher Orden," in "Cura animarum". Seelsorge im Deutschordensland Preußen, ed. Stefan Samerski (Cologne: Böhlau, 20 I3), I 5-43.

4 It was perhaps the knight brothers and their priestly counterparts that most embodied the monastic and knightly-noble amalgam. Reference to the priest brothers is made where appropriate. Other indications apply to the knight brothers, unless otherwise denoted.

Neecke, Literarische Strategien, and Feistner, Krieg.

6 Of the vast and ever-growing body of literature on the castle complex at Marienburg, see in particular: Sławomir Jóźwiak and Janusz Trupinda, "Nazwy pomieszczeń zamku malborskiego w instrumentach notarialnych z końca XIV - pierwszej połowy XV wieku”, Zapiski Historyczne 72, no. 4 (2007): 4 -56; iid., Organizacja życia na zamku krzyżackim w Malborku w czasach wielkich mistrzów (1309-1457) (Malbork: Muzeum Zamkowe, 2019, 2nd edition); iid., "Miejsca wystawiania instrumentów notarialnych w przestrzeni zamku malborskiego w XIV i w pierwszej połowie XV wieku”, Zapiski Historyczne 77, no. 2 (20 I 2): 7-34; iid., "Das Leben auf der Marienburg zur Zeit der Hochmeister (1 309-1457) nach schriftlichen mittelalterlichen Quellen," in Das Leben im Ordenshaus, ed. Juhan Kreem (Weimar: VDG, 2019), 28-39; Tomasz Torbus, Zamki konwentualne państwa krzyżackiego w Prusach (Gdańsk: Historia i Współczesność, 20I4); Kazimierz Pospieszny, Domus Malbork. Zamek krzyżacki w typie regularnym (Toruń: Wydawnictwo Naukowe Uniwersytetu Mikołaja Kopernika, 20 I 4); Christofer Herrmann, "Der Hochmeisterpalast auf der Marienburg. Rekonstruktionsversuch der Raumfunktionen," in "Magister operis." Beiträge zur mittelalterlichen Architektur Europas. Festgabe für Dethard von Winterfeld zum 7o. Geburtstag, eds. Gabriel Dette, Laura Heeg, and Klaus T. Weber (Regensburg: Schnell \& Steiner, 2008), 26I-294; Christopher Hermann, "Kloster - Burg - Residenz: Der Hochmeisterpalast auf der Marienburg im Kontext der Burgenarchitektur des Deutschen Ordens in Preußen," in Ritter, Verwalter und Repräsentanten - Priester und Seelsorger: Burgen, Residenzen und Kirchen des Deutschen Ordens, ed. Helmut Flachenecker (Weimar: vdg, 2016), 37-57; Christopher Hermann, "Die herrschaftlichen Wohnräume im Hochmeisterpalast der Marienburg (Malbork) - ein frühes Beispiel des Stubenappartements im Spätmittelalter," INSITU. Zeitschrift für Architekturgeschichte 2 (2017): 2 I I-228. 
Marienburg - specifically their function and inner constitution, which were long claimed to have corresponded largely to the spiritual plan of Bernard of Clairvaux, ${ }^{7}$ and the exterior, which served more of a military-courtly function in terms of a combination of representation and functional wartime use. Perhaps surprisingly, the literature has granted comparatively less attention to the symbolic gestures envisioned and - at least plausibly - lived out in the brothers' everyday lives. ${ }^{8}$ In short, rituals, their meaning and function, have scarcely enjoyed suitable treatment in the available academic literature. ${ }^{9}$

For the purposes of the current investigation, I should like to discuss ritual as an identity-shaping mechanism in the case of the Teutonic Order with emphasis on the function of symbolic acts as a communicative nexus of cultural memory. As such, the role of collective memory vis-à-vis ritual as suggested in the fields of sociology and the culture of memory are ever-present. The study unfolds in three interconnected moments. Deliberations on ritual theory and its application to the case of the Teutonic Knights subsequently lead to thoughts on collective memory and cultural meaning, which then culminate in an illustration of the delineated principles on the basis of select representational instances.

The pretence of an all-encompassing presentation of known rituals is assuaged by a consciously panoramic view more suited to the parameters of an article. In so doing, the present study does not purport to have discovered new or lesser-known rituals, but merely to offer a nuanced approach to their function and significance

7 Giulia Rossi Vairo outlines this approach and seeks to revise it. See her "Originality and Adaptation: The Architecture of the Teutonic Order in Italy," in Archaeology and Architecture of the Military Orders: New Studies, eds. Mathias Piana and Christer Carlsson (Farnham: Ashgate, 2014), 193-2 18, esp. 193-195.

8 Considerable exceptions include Mentzel-Reuters, "Der Deutsche Orden," and Dieter J. Weiss, "Spiritual life in the Teutonic order: a comparison between the commanderies of Franconia and Prussia," in La commanderie, institution des ordres militaires dans l'Occident médiéval, eds. Anthony Luttrell and Léon Pressouyre (Paris: Comité des Travaux historiques et scientifiques, 200 I), I 59-174, and in particular Marcus Wüst, Studien zum Selbstverständnis des Deutschen Ordens im Mittelalter (Weimar: VDG, $20 \mathrm{I}_{3}$ ).

9 The same also holds true for other military-religious orders. Among minor indications in lesser studies, four more extensive studies distnguish themselves: Berthold Graf Waldstein-Wartenberg, Die "Vasallen Christi." Kulturgeschichte des Johanniterordens im Mittelalter (Köln: Böhlau Verlag, 1988); Jochen Burgtorf, The Central Convent of Hospitallers and Templars: History, Organization, and Personnel (I09g/II20-I3IO) (Leiden-Boston: Brill, 2008); Bernd Schwenk, Calatrava. Entstehung und Frühgeschichte eines spanischen Ritterordens zisterziensischer Observanz im I2. Jahrbundert (Münster: Aschendorff, 1992); and El nacimiento de la orden de Calatrava. Primeros tiempos de expansión (siglos XII y XIII). Actas del I Congreso Internacional de la Orden de Calatrava. Almagro, octubre 2008, eds. Ángela Madrid y Medina and Luis Rafael Villegas Díaz (Ciudad Real: Instituto de Estudios Manchegos, 2009). 
as lived embodiment of cultural meaning. Thus, the investigation largely serves to display a phenomenon in principle - a principle, which could be applied to a broad swath of ritual acts in the life of the Teutonic Knights, but which finds particular specificity in the chosen case study in light of the insights offered by J. Assmann and with regard for the order's dual model of identity. At the same time, the previous statement should not be taken to mean that the order's rituals or their corresponding envisaged collective identity were entirely unique in nature and without parallel in other medieval communal arrangements. In fact, every endeavour to establish or to legitimise an identity is contextual and is thereby predicated on an identifying agent (whether individual or collective) who constructs from the elements available to them, some of which may also pertain to that of others. Identity construction is - more often than not - a patchwork endeavour. To (self-) identify is inevitably to absorb and appropriate, albeit of course to varying degrees. This axiom holds true especially in medieval cultural settings. By the same token, however, this and other of the author's studies ${ }^{10}$ seek to cultivate a concerted appreciation of the major features concerning the order's idiosyncratic institutional arrangement and its forms of expression and - more to the point in the present instance - to view them through the lens of collective memory.

\section{Rituals and Collective Identity in the Teutonic Order}

In accordance with much of contemporary ritual theory, symbolic acts refer generally to all forms of emblematic, visible, and bodily enactment of guiding principles. Distinct from signs, symbols not only represent but embody - and in the moment of their enactment, ultimately are - the ideals to which they refer. They render present the guiding principles of a community. There are traditionally two forms of symbolic acts: repetitive rituals and unique performative acts. ${ }^{11}$ Whereas rit-

Io While other lesser studies can be found in the footnotes of this study, the project from which the current paper originated is DFG Forschungsvorhaben: "Seelenheil und Ritterehre: Die Identität des Deutschen Ordens im Spiegel seiner Symbolhandlungen”. The broader project analyses the extent to which monastic and courtly-noble conceptions of life, self-image, and modes of conduct coalesced in the military-religious orders as well as the manners in which ritual conduct and performative acts contributed to the formation of a specific identity - and that based upon a threefold scheme (monastic - courtly-noble - mixed form).

II Of the immense bibliography on symbolic acts and the application of ritual theory in historical contexts, see in particular: Gerd Althoff, Die Macht der Rituale: Symbolik und Herrschaft im Mittelalter (Darmstadt: WBG, 2013, 2nd edition); id., Spielregeln der Politik im Mittelalter. Kommunikation in Frieden und Fehde (Darmstadt: WBG, 1997); Die Spielregeln der Mächtigen: mittelalterliche Politik zwischen Gewohnheit und Konvention, eds. Claudia Garnier and 
uals are marked by their repetitive and formulaic qualities, performance regards singular, situational events. Rituals are firmly connected with a regulated, trans-situational form. In contrast, performative acts are intimately linked to a singular, bodily enactment adapted to the circumstance. ${ }^{12}$ Both forms of conduct are a central means of visible presentation of symbolic arrangement and as symbolisations of guiding principles are able to contribute to the construction and establishment of a unique collective identity. Symbolic gestures are thus understood here not only in terms of mechanisms of visual semiotics, but also as symbols acted out and embodied either in pre-patterned or in singular moments. As G. Melville has astutely observed, a key insight into the difference between rituals and performative acts lies in the matter of their recountability. ${ }^{13}$ While rituals are designed to unfold in the same fashion in accordance with a pre-established pattern and are therefore repetitive in nature, performative acts, although they also refer to and embody guiding principles, are the product of spontaneity and thus merit recounting. Giv-

Hermann Kamp (Darmstadt: WBG, 20 10); Riten, Gesten, Zeremonien: Gesellschaftliche Symbolik in Mittelalter und Früher Neuzeit, eds. Edgar Bierende, Sven Bretfeld, and Klaus Oschema (Berlin: De Gruyter, 2008); Joachim Bumke, Höfische Kultur im hohen Mittelalter (München: Deutscher Taschenbuch Verlag, 2008, I 2th edition); Die Perfomanz der Mächtigen. Rangordnung und Idoneität in höfischen Gesellschaften des späten Mittelalters, eds. Klaus Oschema, Cristina Andenna, Gert Melville, and Jörg Peltzer (Ostfildern: Jan Thorbecke Verlag, 20 I 5); Werner Paravicini, Die ritterlich-höfische Kultur des Mittelalters (München: De Gruyter Oldenbourg, I998); id., Die Preußenreisen des europäischen Adels, 2 vols. (Sigmaringen: Thorbecke, 1 989-1995); Zeremoniell und Raum, Potsdam, 25. bis 27. September 1994, ed. Werner Paravicini, Symposium der Residenzen-Kommission der Akademie der Wissenschaften in Göttingen 4 / Residenzenforschung 6 (Sigmaringen: Thorbecke, I 997); Höfische Repräsentation. Das Zeremoniell und die Zeichen, eds. Hedda Ragotzky and Horst Wenzel (Tübingen: WBG, 1990); Gerrit Jasper Schenk, Zeremoniell und Politik. Herrschereinzüge im spätmittelalterlichen Reich (Köln: Vandenbhoeck \& Ruprecht, 2003). Further fruitful explorations of the ritual-historical approach can be found - to name just two works - in Im Spannungsfeld von Recht und Ritual: Soziale Kommunikation in Mittelalter und Früher Neuzeit, eds. Heinz Duchhardt and Gert Melville (Köln: Böhlau, 1997), and more recently in Grenzen des Rituals: Wirkreichweiten Geltungsbereiche - Forschungsperspektiven, eds. Andreas Büttner, Andreas Schmidt, and Paul Töbelmann (Köln: De Gruyter, 20 I 4).

12 For studies on the written word and diplomatic gestures as ritual and performative expressions of sovereign networks, see Geoffrey Koziol, The Politics of Memory and Identity in Carolingian Royal Diplomas: The West Frankish Kingdom (840-987) (Turnhout: Brepols, 201 2), and id., Begging Pardon and Favor: Ritual and Political Order in Early Medieval France (Ithaca-London: Cornell University Press, I 992 ).

13 Gert Melville, "Der historische Moment, das Repertoire und die Symbolik. Resümierende Überlegungen zu Beiträgen über performatives Handeln,” in Die Perfomanz der Mächtigen. Rangordnung und Idoneität in höfischen Gesellschaften des späten Mittelalters, eds. Klaus Oschema, Cristina Andenna, Gert Melville, and Jörg Peltzer (Ostfildern: Jan Thorbecke Verlag, 2015), 217-234. 
en that rituals - insofar as they are to follow a pre-determined pattern agreed upon and established in a communal context - are more closely aligned with the establishment and preservation of cultural memory, they are duly situated at the centre of the present study's thematic focus.

As indicated, major features of the Teutonic Order's collective identity have their foundation in the cultural traditions of monasticism and noble life. Indeed, this military-religious order drew from the deep wells of monastic and courtly-noble identity. Corresponding to the order's dual societal consciousness, it adhered to both models of life to varying degrees at an institutional level. The orchestration and enactment of ritual acts served as a prime apparatus of said adherence. A notable share of their rituals had its origin in the worlds of monasticism and the noble court, while others reflected an influence from both cultural spheres at once. ${ }^{14}$ To the extent that the Teutonic Knights constituted an ordo of the Latin Church, it adopted and adapted select practices of daily life from monastic contexts, a substantial portion of which derived from the injunctions and the spirit of the Regula Benedicti, the foundation of Western monasticism. ${ }^{\text {is }}$ As sanctioned fighters of holy wars and ultimately as territorial sovereigns, they also implemented practices that were reflective of noble-courtly culture as a means of bolstering their claim to legitimacy. The ideals of both the monastery and the court thus infiltrated their everyday lives in tangible and visible fashion. Perhaps the most striking of these instances, the community's rituals embodied and encapsulated their hybrid nature. The order's dual social inclusion was characterised by the difficulty regarding the model of a knight-monk. Whereas the courtly culture of the nobility was anchored in the worldly, monastic life served to leave the world and its ways behind. Verbalised justifications for the military orders' statal duality generally have their roots in what we may call a spiritual knighthood or militia Christi in the nomenclature of Bernard of Clairvaux, which was an attempted fusion between crusading mentality and a tinge of Cistercian spirituality. ${ }^{16}$ The notion of a spiritual knighthood was a socially contentious and theologically edgy one, even

I4 A few sporadic cases may prove outliers. One such instance was the potential practice of funeral pyres and religious cremation, which the author addresses in Nicholas W. Youmans, "Rituals of Mobility and Hospitality in the Teutonic Knights," East Central Europe 47 (2020): 48-50.

is On language of spiritual struggle in the Rule of Benedikt and the Teutonic Knights, see: Ewald Volgger, "Entstehung, Aufbau, Mitgliedschaft und Hierarchie im Deutschen Orden unter Berücksichtigung des Gesamtphänomens der geistlichen Ritterorden," in Die Regeln des Deutschen Ordens in Geschichte und Gegenwart, ed. Ewald Volgger (Vienna: Deutschordens-Verlag, I985), 24-25.

16 The institutional tension of the model of a knight-monk was already recognised in Bernard of Clairvaux's treatise De laude novae militiae. See: Josef Fleckenstein, "Die Rechtfertigung der geistlichen Ritterorden nach der Schrift 'De laude novae militiae' Bernhards von Clairvaux," in 
in the time of the crusades. ${ }^{17}$ Distinct from the arguments of classical just war theory $^{18}$ - the idea that 'it's dirty work, but someone's got to do it', so to speak -, this model also insisted that not only did the struggle of the military-religious orders serve an attainable greater good, but more boldly that the fighting itself was in some way religiously meritorious and - in its fullest expression - would lead its combatants to encounter Christ in wielding the sword against the enemies of Christendom. This model received mixed reviews in its time, particularly as fighting implied the shedding of blood, a mortal sin and an act strictly forbidden the spiritual estate since the time of Gratian. ${ }^{19}$

An appraisal of the source material has revealed - as indicated - that not only do prominent symbolic acts of the military orders relate either to knighthood or monasticism, but they also concern both identity models at once. ${ }^{20}$ As such, the rituals and performative acts of the military orders refer to overarching ideals of both the religious and noble-knightly states. It is along this threefold scheme that my project seeks to gain a better understanding of the peculiarity of the military-re-

Die geistlichen Ritterorden Europas, eds. Josef Fleckenstein and Manfred Hellmann (Sigmaringen: Thorbecke Jan Verlag, I 980), 9-22.

17 On criticism of the crusades within Christian circles, see: Elizabeth Siberry, Criticism of Crusading: Iogs-I274 (Oxford: Clarendon Press, 1985); Rudolf Hiestand, "Gott will es!" - Will Gott es wirklich? Die Kreuzzugsidee in der Kritik ihrer Zeit (Stuttgart: Kohlhammer, 1998); and Martin Aurell, Des chrétiens contre les croisades: (XII $-X I I I^{e}$ siècle) (Paris: Fayard, 2013). Specifically, regarding critique of the military-religious orders, see: Loïc Chollet, "Croisade ou évangélisation? La polémique contre les Chevaliers Teutoniques à l'aune des témoignages des voyageurs français de la fin du Moyen Âge," Ordines Militares Colloquia Torunensia Historica. Yearbook for the Study of the Military Orders 20 (2015): 175-203; id., "Les Voyages en Prusse vus de France: la perception de la croisade contre la Lituanie dans quelques sources francophones (fin XIV - début XV siècle)," Studia z Dziejów Średniowiecza I 9 (20 I 5): 5 I -80.

18 For an examination of classical just war theory in Augustine, see: John Mark Mattox, Saint Augustine and the Theory of Just War (New York-London: Continuum, 2006). On the matter of just war among the Teutonic Knights, see: Rasa J. Mazeika, "Violent Victims? Surprising Aspects of the Just War Theory in the Chronicle of Peter von Dusburg," in: The Clash of Cultures on the Medieval Baltic Frontier, ed. Alan V. Murray (Farnham: Routledge, 2009), I 23- I 40.

19 On the origins of the Church's stance on violence among the clergy in canon law, see: Günter Jerouschek, "'Ecclesia non sitit sanguinem'," in Handwörterbuch zur deutschen Rechtsgeschichte, vol. I, Aachen - Geistliche Bank, ed. Albrecht Cordes (Berlin: Erich Schmidt Verlag, 2008, 2nd edition), I I 74- I 176 .

20 The current paper was developed during the execution of a research project - DFG Forschungsvorhaben: "Seelenheil und Ritterehre: Die Identität des Deutschen Ordens im Spiegel seiner Symbolhandlungen" -, which analyses the extent to which monastic and courtly-noble conceptions of life, self-understanding, and modes of conduct coalesced in the military-religious orders as well as the manners in which ritual conduct and performative acts contributed to the formation of a specific identity on the basis of a threefold scheme (monastic - courtly-noble - mixed form). 
ligious orders. Thus not only did members of the Teutonic Order undertake rituals typical of monastic communal asceticism and discipline such as observing silence, prayers and kneeling rituals, orchestrated seating at meals and other events, ritualised punishments, processions, and so on, in addition to chivalric and noble acts such as knighting ceremonies, the exchanging of gifts with other rulers, treaty ceremonies, traveling with a courtly entourage, the ruler's adventus, and so on, but they also proclaimed and lived out their hybrid societal state with gestures of a hybrid nature. Of these, some are discussed below. Their rituals thus constituted instances of both the traditional and the innovative, in that, they may be considered a creative melding and bringing to expression of both past and present.

\section{Collective Memory, Cultural Meaning, and Rituals}

An analysis regarding the rituals of the Teutonic Knights as a symbolic means of embodying and communicating tradition calls for a retracing of certain developments and definitions from the spheres of sociology and cultural history, chief among which is that of collective memory as expressed in its various forms. Select studies have examined the order's festive commemorations centred around liturgical occasions and historical places and events with an accent upon the Holy Land. ${ }^{21}$ The current investigation, however, sets out to consider the order's rituals - more fundamentally - as manifestations of enacted living memory (or collective identity) embodied and communicated in concrete, choreographed symbolic moments. In particular, the thoughts of J. Assmann on cultural memory offer unique insight into the dynamics of ritual as living tradition in historical contexts. ${ }^{22} \mathrm{~A}$ brief delin-

${ }_{21}$ See in particular: Ewald Volgger, "Die Feier von Kreuzauffindung und Kreuzerhöhung. Ursprung, Verbreitung und Bedeutung unter besonderer Berücksichtigung als Hochfeste des Deutschen Ordens," in Beiträge zur Geschichte des Deutschen Ordens, vol. I, ed. Udo Arnold (Marburg: Elwert, I 993), I-50; Krzysztof Kwiatkowski, "Christ ist erstanden... and Christians win! Liturgy and the Sacralization of Armed Fight against Pagans as Determinants of the Identity of the Members of the Teutonic Order in Prussia," in Sacred Space in the State of the Teutonic Order in Prussia, ed. Jarosław Wenta (Toruń: Wydawnictwo Naukowe Uniwersytetu Mikołaja Kopernika, 2013), I0 I-I 29.

22 His foundational publication for the theory of cultural memory is Jan Assmann, Moses the Egyptian: The Memory of Egypt in Western Monotheism (Cambridge: Harvard UP, 1 998). The theories presented here were of course developed in conjunction with his wife Aleida Assmann. For a representative work in which their theories are expanded and applied, see: Mnemosyne. Formen und Funktionen der kulturellen Erinnerung, eds. Aleida Assmann and Dietrich Harth (Frankfurt/Main: Fischer-Taschenbuch-Verlag, 1993). 
eation of his theory and sources of inspiration as they relate to the present matter seems an appropriate point of departure for the study's deliberations.

Though likely originated by É. Durkheim, the concept of collective memory was developed and popularised by his pupil, sociologist and philosopher M. Halbwachs in such seminal works as Les Cadres sociaux de la mémoire and the posthumously issued La mémoire collective. As J. K. Olick puts it, Halbwachs's essential insight was that the study of collective memory was expressly not a matter of "reflecting philosophically on inherent properties of the subjective mind" ${ }^{23}$ what J. Assmann refers to as the inner level of memory or "our neuro-mental system." ${ }^{24}$ Instead, he discussed memory as a matter of "how minds work together in society" or "how their operations are structured by social arrangements." 25 Halbwachs argued that there are two ways of relating the past to the present, contrasting 'history' with 'collective memory.' For him, both are publicly available and determined by social factors, but the former was 'dead' and the latter 'living.' J. K. Olick encapsulates the notion well when he writes, "History is the remembered past to which we no longer have an 'organic' relation - the past that is no longer an important part of our lives - while collective memory is the active past that forms our identities. ${ }^{26}$ In other words, as Halbwachs expressed in his study of the topography of sacred sites in the Holy Land, ${ }^{27}$ on a collective scale, memory is something that emerges when localised in a sacred space or when otherwise constructed socially.

Since the time of Halbwachs and despite some of his initial intuitions, much of the focus in the area of collective memory studies has been on the various ways in which history and collective memory relate to one another. Theoreticians have largely concentrated on textual sources and the collective construction of history or the social reception of historical facts. Comparatively less attention has been granted to the phenomenon that provided the original impetus for such reflections; namely, studies on the commemoration involved in religious rites and rituals. One sociological camp, whose deliberations are perhaps most compatible

${ }_{23}$ Jeffrey K. Olick, "From Collective Memory to the Sociology of Mnemonic Practices and Products," in A Companion to Cultural Memory Studies, ed. Astrid Erll (Berlin: De Gruyter, 20 Io), I 55 .

24 Jan Assmann, "Communicative and Cultural Memory," in Cultural Memory Studies. An International and Interdisciplinary Handbook, eds. Astrid Erll and Ansgar Nünning (Berlin: De Gruyter, 2008), I09.

25 Olick, "From Collective Memory," 155.

26 Jeffrey K. Olick, “Collective Memory: The Two Cultures," Sociological Theory I 7, no. 3 (1 999): 335.

27 M. Halbwachs, La topographie légendaire des Évangiles en Terre sainte: étude de mémoire collective (Paris: Presses Univ. de France, I 94 I). 
with my approach, is that of the inelegantly named mnemohistory spearheaded by German intellectuals such as J. Assmann, which "(u)nlike history proper [...] is concerned not with the past as such, but only with the past as it is remembered." ${ }^{28}$ J. Assmann thus expands ideas on collective memory from the realm of the social to that of culture. In his view, history is not so much an objectivised series of events, but "an active process of meaning-making through time," ${ }^{29}$ or "the ongoing work of reconstructive imagination." ${ }^{\circ}$ With J. Assmann, collective memory becomes 'cultural memory' a term which he is careful to attribute to his wife Aleida. As distinct from the communicative variety, cultural memory represents a "kind of institution" that is "exteriorized, objectified, and stored away in symbolic forms," which in turn "are stable and situation-transcendent." ${ }^{31} \mathrm{~J}$. Assmann then delineates external factors - what he refers to as carriers of memory, in relation to which cultural memory subsists. Just as our private memories exist "only in constant interaction [...] with other human memories" and "with things" or "outward symbols," so too does the collective memory of a social entity, which "also exists in disembodied form" require constant re-embodiment in the form of symbols. ${ }^{32}$ For a collective, symbols are in other words "suffused with pastness" ${ }^{33}$ as William James declared analogously of a mental image for an individual, insomuch as they supply a community with continuities and references of habit and custom, thereby allowing a collective to "reproduce its identity." ${ }^{34}$ Custom and habit become symbol by means of ritual acts, in that they render present and concretise transcendent principles in support of a self-perpetuating institutional arrangement. In short, ritual enacts (collective) identity. It does so by embodying the living memory stored within the visible and tangible form of an orchestrated act.

In a co-authored essay entitled Collective Memory and Cultural Identity, J. Assmann specifies the meaning of cultural memory in reference to 'figures of memory,' or "fateful events of the past, whose memory is maintained through cultural formation (texts, rites, monuments) and institutional communication (recitation, practice, observance)." ${ }^{35}$ In such formation, "a collective experience crystalliz-

28 Assmann, Moses the Egyptian, 8-9.

29 Olick, "From Collective Memory," I 52.

30 Assmann, Moses the Egyptian, I 4.

3 I Assmann, "Communicative and Cultural Memory," i i o- I I I .

32 Ibid., I I 1 .

33 William James, Manuscript Essays and Notes (Cambridge, Ma: Harvard University Press, I988), I 3 .

34 Jan Assmann and John Czaplicka, “Collective Memory and Cultural Identity," New German Critique 65, no. 2 (1995): I 28 (originally published in Kultur und Gedachtnis, eds. Jan Assmann and Tonio Holscher (Frankfurt a. Main: Suhrkamp, I 988), 9-I9).

35 Assmann and Czaplicka, "Collective Memory and Cultural Identity" i 28- I 29. 
es, whose meaning, when touched upon, may suddenly become accessible again across millennia." He then stresses the dimensions of cultural memory in sixfold fashion with which we will analyse a few select examples of rituals among the Teutonic Knights. Firstly, cultural memory involves the 'concretion of identity'or the relation of the individual to the group, which, when formulated positively and negatively, amounts to statements of collective meaning such that one may affirm ('what we are') and negate ('what we are not') various concrete elements. Cultural memory also has the capacity to reconstruct or "relate its knowledge to an actual and contemporary situation," by way of appropriation, criticism, preservation, or transformation. Next, cultural memory requires the crystallisation of shared meaning and knowledge in order to be transmitted. It requires 'stable' formation in the form of textualization, pictorial images, rituals, and so on. Reconstruction and formation are thus predicated on organisation, or the institutionally formulised practices and ceremonies. Obligation also accompanies the institutionalisation of cultural meaning, whereby a normative self-image of the group is transferred into and realised by a clear system of values. Finally, cultural memory possesses a threefold reflexive quality, in that, it interprets common practices, it draws upon itself in relation to other elements, and it "it reflects the self-image of the group through a preoccupation with its own social system." "The concept of cultural memory," he argues, "comprises that body of reusable texts, images, and rituals specific to each..." ${ }^{6}$ collective, which render present, that is, re-present transcendent meaning. Let us now examine how this theoretical framework can be applied to the life of the Teutonic Order.

\section{Cultural Memory and the Rituals of the Teutonic Knights}

With his deliberations, J. Assmann opens up expansive avenues for reflection on symbolic acts as conductors of cultural meaning, that is of living memory. Select instances have been chosen to reflect the variety of symbolic gestures of which the order was availed, that is, acts with an internal, public, and participatory setting. In such a way, the discussed conceptual framework will be applied to circumstances relating to the dynamics of ritual as articulated exclusively within a communal context, in the presence of non-members, and also as it relates to the involvement of outsiders. Let us now turn to a few pertinent examples from the life of the Teutonic Knights. Three brief examples should suffice to illustrate the principles at hand. First, we have the ritual of admission into the order.

36 Ibid., I 29-132. 


\section{The Rite of Initiation}

As with other religious orders, the Teutonic Knights sought to recruit and induct new members who suited the institution and shared in its sense of mission. ${ }^{37}$ To mark the solemn occasion of induction into the community, an internal ceremony was held before the master and the entire chapter..$^{38}$ The ritual had the aspirant request acceptance into the community and promise an oath of obedience to the master and the order at large, which expressly comprised the goals of the institution, namely armed combat against the pagans and hospital service, even into the fourteenth century when order hospitals were ever scarcer. ${ }^{39}$ The two spheres of activity reflect the order's self-understanding in the form of their dual state in society. They were consciously engrossed in both the knightly-noble and monastic cultural spheres, a reality which their members fully embraced in this utmost symbolic act. With his hand placed upon the Gospel, the candidate swore chastity, poverty, and obedience to God, to Mary, and to the Grand Master - though the Grand Master's presence likely would have been relieved by a vicar in many cases. The candidate was then given bread and water and asked to don tattered old garments - symbols of voluntary poverty and a gesture embodying the candidate's willingness to endure the hardship of their communal life. Only then was he granted his new garb, the habit or cloak of the Teutonic Order, which symbolised the embracing of his new existence and acceptance on the part of the community.

A priest brother was then to bless the knight brother (benediccio) - an act likely in part derived from secular knighting ceremonies -, thereby integrating both monastic and knightly-noble elements. Here, a priest brother girded the candidate with a sword and blessed him, a symbol, which since Roman times exhibited one's authority and high social standing. The admission ceremony then concludes with the priest evoking the tasks to which the new member was called: he was to be a combatant against non-believers and a protector of the Church, of widows,

37 On the recuitment and reception of new brothers into the Teutonic Knights, see: Klaus Militzer, "Die Aufnahme von Ritterbrüdern in den Deutschen Orden. Ausbildungsstand und Aufnahmevoraussetzungen," in id., Zentrale und Region: gesammelte Beiträge zur Geschichte des Deutschen Ordens in Preussen, Livland und im Deutschen Reich aus den Jabren 1968 bis 2008 (Weimar: VDG, 2015), 45-54.

${ }_{38}$ Die Statuten des Deutschen Ordens nach seinen ältesten Handschriften, ed. Max Perlbach (Halle: Max Niemeyer, I 890), I 27, "Aufnahmeritual". This was similar to that of the Knights of St. John, but additional prayers are also added in the form of Benediccio ad militem, Benediccio ad vestiendum fratrem and Ordo ad consacrandum clericoum. See: Die Statuten, ed. Perlbach, no. 29, "Regel".

39 For an overview of the Order's function and activity as a charitable institution with particular regard for its hospital service, see: Klaus Militzer, "Die Hospitaltätigkeit des Deutschen Ordens," in id., Zentrale, $63-76$. 
and of orphans. Echoes of both the code of chivalry and of the monastic principles of hospitality from Matthew 25 can be detected here. ${ }^{40}$ As such, the ceremonious act constitutes a prime example of cultural memory unfolding in encapsulated, ritual form. The institutional identity of the Teutonic Knights is animated and perpetuated with the lived iteration of the ritual. In line with J. Assmann's school of thought the act serves the role of a concrete symbolic gesture which manifests and renders present the community's collective memory. As with monastic hospitality, the life of the Teutonic Knights was embedded in an almost sacramental dimension, with their entire mission conceived as an encounter with Christ, albeit in a completely new context than before in the religious orders of the Middle Ages, namely, that of the knighthood and combatting non-believers - a dimension, which in turn corresponds notably to the order's symbiosis of two cultural spheres.

As a consequence, the admission ceremony furnishes a demonstrative case of an embodied moment of the order's collective memory, a symbolic confluence regarding two usually diverse streams of identity, which was reflective of guiding principles evocative of the Teutonic Knights as an organisation, its mission and overarching value structure rooted in both the monastic and the courtly-noble. In conducting such an internally-oriented act, those present collectively recalled and conveyed to themselves and one another their shared identity and in particular their sense of duty, code of conduct, and united self-image. Not only the sworn oath of the brother-to-be, but the group's common commitment exhibited on the occasion bring their disembodied ideals to life. While the aspirant and the Grand Master (or potentially his respective vicar) were at the centre of the ritual itself, the presence, approval, and active acceptance of the other brothers, who welcomed the new member into their fold in an intramural fraternal setting, asserted and heightened the communal dimension of the act. With the act, not only was a new member initiated; rather, and more fundamentally, all those present conjointly reaffirmed and reinstated their collective institutional identity.

40 On the matter of hospitality and rituals in the Teutonic Knights, see: Youmans, "Rituals". For an overview of the broader research project from which the current study originates, see: id., "Seelenheil und Ritterehre. Vorstellung eines Forschungsprojekts zur Identität des Deutschen Ordens im Spiegel seiner Symbolhandlungen “, in Der Deutsche Orden auf dem Konstanzer Konzil: Pläne - Strategien - Erwartungen, ed. Helmut Flachenecker (Weimar: VDG Verlag, 2020), I 57-175. 


\section{Solemn Procession at Marienburg}

Having addressed a prominent scenario of collective memory as played out in an internal ritual setting, let us now consider a symbolic act in terms of more public affair. Much reflection has taken place of late on the symbolic configuration of daily life in the military-religious order's main Prussian seat, Marienburg. The symbolic acts that were undertaken as a part of the overall structure and meaning of their existence there were undoubtedly among the most eye-catching as well as demonstrative of collective self-understanding and are as a result worthy of note. A prominent instance of embodied symbolisation is that concerning the solemn processions and exposition of various precious relics housed at the complex in Marienburg, ${ }^{41}$ a comparatively more public act. Though it was conducted by the order, it also involved the presence of a public audience. As is well known, the Teutonic Knights over time came to acquire numerous remains of saints and holy artefacts, including relics of Sts. Agatha, Euphemia, Elisabeth, Katherine, Anthony, and for a time Barbara (or Dorothy), of whom the order had also obtained a holy image that was carried about in processions. ${ }^{42}$ One will notice that with the exception of Anthony, common threads of these remains are femaleness, virginity, and martyrdom - a powerful statement in and of itself, most assuredly employed to encompass their societal status in terms of nobility. By the same token, it constituted a symbolic reference on an institutional level, which identified them as white martyrs whose lives were dedicated to the rigors of the monastic life, but it also referred in symbolic fashion to their willingness to be red martyrs and die for the faith. Of particular interest among the holy objects were the famed particles of the Holy Cross (lignum sancte crucis or heilig holz, depending on the source $)^{43}$

${ }^{4}$ In addition to architectural and art historical considerations, the two main sources for the processions and reliquary exposition are Petrus de Dusburg, "Chronicon terrae Prussiae," ed. Max Toeppen, in Scriptores rerum-Prussicarum, eds. Theodor Hirsch, Max Toeppen, Ernst Strehlke, vol. I, (Leipzig: S. Hirzel, I 85 I), 206-208 n. 77/78, and Das Ausgabebuch des Marienburger Hauskomturs für die Jahre I4IO-I420, ed. Walther Ziesemer (Königsberg: Thomas \& Oppermann, I 9 I I ), 463. On the feasts of the Kreuzauffindung and the Kreuzerhöhung in the Teutonic Order, see: Volgger, "Die Feier."

42 Das Marienburger Ämterbuch, ed. Walther Ziesemer (Danzig: A. W. Kafemann, G.m.b.H, I916), I22-135. On Marienburg as a pilgrimage site and on the specifics of the relics housed there, see: Rainer Zacharias, "Die Marienburg als Wallfahrtsstätte," in Burgen kirchlicher Bauherren, ed. Thomas Biller (Munich: Dt. Kunstverl, 200I), 49-60; Rainer Zacharias, "Die Reliquienwallfahrt zur Hochmeisterresidenz Marienburg," Zeitschrift für die Geschichte und Altertumskunde Ermlands 50 (2002): I I-36.

43 Petrus de Dusburg, "Chronicon terrae Prussiae," ed. Toeppen, 53 n. 5; "Di Kronike von Pruzinlant," ed. Strehlke, 3 I 6 n. I I I9-1 I 42, and "Gnadenbrief für die S. Lorenz-Kapelle in der Marienburg", in Johannes Voigt, Geschichte Marienburgs, der Stadt und des Haupthauses des 
entrusted to the order's care, one of which was said to have been granted them by Emperor Frederick II, a symbolic gesture in its own right, expressing his condonement and blessing of the community's perpetual mission to undertake crusade in the territory of Prussia.

As is known, the various relics at Marienburg had alternating whereabouts that indicate their exposition and use in para-liturgical practices. ${ }^{44}$ The communal processions enacted for reliquary exposition offered occasion for highly symbolic moments that regarded collective identity in particular fashion. From its early days, Marienburg was a hot spot for pilgrimages. A papal charter (1358) even grants a 40-day indulgence to those who visit and bear witness to the relics of the Holy Cross at this site.45 Pilgrims flocked when the relics were brought forth on special occasions and carried in procession to an altar erected in a meadow located in front of the fortress complex. Particularly on the high feast of the Finding of the Holy Cross (Gm. Kreuzauffindung), the procession led through the cloister, through the chapel of St. Anna, which was a known burial site of the Hochmeister and funeral ceremonies with its depictions of significant moments of the history of salvation, namely of the Final Judgment and of the Kreuzauffindung. ${ }^{46}$

From highly emblematic location of the St. Anna's chapel the procession subsequently led outside and concluded in the aforementioned meadow at the altar, directly beneath the gaze of the Madonna mosaic affixed on the outermost facade of the castle church's apse until I 4 I $0 .{ }^{47}$ Not only did it amount to a re-enactment of the legend of St. Helena and the finding of the True Cross relic, the occasion and setting of the symbolic act was a public embodiment of the military-religious order's identity in terms of its dual societal inclusion and corresponding spheres of activity as well as the original mission to undertake crusades in the Holy Land. One can imagine that the prayers of the solemn mass on the occasion of the Kreuzauffindung rang particularly true in conjunction with the occasioned gathering of the Teutonic Knights and the faithful crowds and the collective celebration of the sacred objects, which contains references to the order's broader role. The prayer of thanksgiving touting the wood of the Holy Cross as a salvific weapon of justice

deutschen Ritter-Ordens in Preußen (Königsberg: Gebrüder Bornträger, I 824), 586-587 (Source edition No. VII).

44 Kazimierz Pospieszny, "Orte der Reliquienpräsentation in den Deutschordensburgen in Preußen: ein Beitrag zu neueren Forschungen," in "Ecclesiae ornatae." Kirchenausstattungen des Mittelalters und der frühen Neuzeit zwischen Denkmalwert und Funktionalität, eds. Gerhard Eimer, Ernst Gierlich, and Matthias Müller (Bonn: Kulturstiftung d. dt. Vertriebenen, 2009), $311-326$.

45 "Gnadenbrief", 586-587.

46 Zacharias, "Die Reliquienwallfahrt", 30-32.

47 A potential reconstruction of the event is conducted in ibid., I I-26. 
surely must have come to life in such momentous occurrences (ut ab haste maligno defendas. quos per lignum sancte crucis filii tui armis iustitiae per salute mundi triumphare iussisti). $4^{8}$

In addition, supplying the poor with ample sustenance was customary on various occasions of the year, especially on significant feast days. As a symbol of the order's dedication to hospitality and the care for others - both noble and monastic in origin - pilgrims received alms and other special treatment likely in accordance with their social standing. Therefore, although guests were hosted at Marienburg only in exceptional cases, ${ }^{49}$ pilgrims were provided with nourishment of both a spiritual and gastronomic nature. Considered in an organic context, the act thus constituted a compact, self-referential carrier of cultural memory, in Assmann's terms, a nexus of trans-situational ideals - in this case also in association with the commemoration of past events - and present identity-shaping acts. The order made a self-reflexive proclamation for themselves and before the audience gathered to bear witness. With it, they brought forth in condensed fashion the collective memory and thereby conjointly recalled the overarching value structure of their organisation in an affirmative celebration of their institution, its function and meaning. It is ultimately no coincidence that the procession and reliquary exposition that culminated beneath the church's Marian mosaic depicted as the Queen of Heaven and Mother of all the faithful - two motifs, which symbolise the order's noble and religious (indeed monastic) characteristics.

In order to place such an emblematic act in context, one could juxtapose this sort of procession with those undertaken in traditional religious orders and medieval towns and indeed with other processions carried out by the Teutonic Order. The 'spatial turn' of cultural and liturgical studies allows us to gain insight into the processional worship conducted in diverse contexts of the medieval Latin West. ${ }^{\circ}$

48 Antoine Chavasse, Le sacramentaire gélasien (Vaticanus Reginensis 3I6): sacramentaire presbytéral en usage dans les titres romains au VIIe siècle (Tournai: Desclée, 1957), 355. Chavasse astutely remarks that the prayer appropriately originated as a supplicatory call to God to protect against demons on the battlefield.

49 For context on hosting guests at Marienburg and Königsberg, see: Werner Paravicini, Die Preußenreisen des europäischen Adels, vol. I (Sigmaringen: Thorbecke, I989), 276, and Jóźwiak and Trupinda, Organizacja, 302-3 I I.

so Of the manifold historical and phenomenological studies on the topic, see in particular: Prozessionen und ibre Gesänge in der mittelalterlichen Stadt: Gestalt - Hermeneutik - Repräsentation, eds. Harald G. Buchinger, David Hiley, and Sabine Reichert (Stuttgart: Schnell \& Steiner, 2017); C. Clifford Flanigan, "The moving subject: Medieval liturgical processions in semiotic and cultural perspecti," in Moving Subjects: Processional performance in the Middle Ages and the Renaissance, eds. Kathleen M. Ashley and Wim N. M. Hüsken (Amsterdam-Atlanta, Ga: Rodopi, 200 I), 35-5 I; Sible de Blaauw, "Following the crosses: The processional cross and the 
Of course, the act has certain elements in common with medieval religious processions of a similar ilk. The carrying of relics and other sacred objects as well as the visiting of significant sites in procession on marked occasions was assuredly not entirely unique to this instance. ${ }^{51}$ It is, however, the specific identity-bearing content of the visited and inhabited space and the spatial choreography alongside the individual profile of the revered relics and the interaction between order members and pious pilgrims taken into account as an organic whole, which bears traces of precise shared meaning. Any commonalities in other communities only add to the legitimacy of their endeavour. Additionally, the Teutonic Order also held symbolic events involving processions - to varying degrees - as an extension of their territorial sovereignty, prominent examples comprise the adventus regis ${ }^{2}$ and the crowning of Prussian Bishops at the castle complex of Marienburg. ${ }^{33}$ Such events were often laden with strong representational and hegemonic overtones and were more akin to a display of institutionalised hierarchical power. This too can be viewed as a lived expression and embodiment of their link to the courtly-noble identity model, though it is worth noting that the order afforded a vast assortment of ritual practices that comprised their symbolic repertoire.

typology of processions in medieval Rome," in Christian Feast and Festival: The Dynamics of Western Liturgy and Culture, eds. Paul Post, Gerard A. M. Rouwhorst, Louis van Tongeren, and A. Scheer (Leuven: Peeters, 2001), 319-343; Roger E. Reynolds, "The drama of medieval liturgical procession," Revue de musicologie 86 (2000): I 27-I 42; Medialität der Prozession: Performanz ritueller Bewegung in Texten und Bildern der Vormoderne / Médialité de la procession: performance du mouvement rituel en textes et en images à l'époque pré-moderne, eds. Katja Gvozdeva and Hans Rudolf Velten (Heidelberg: Universitätsverlag Winter GmbH, 20 I I ). On pilgrimage, processions, and sacred space in the Holy Land involving the military-religious orders, see Shlomo Lotan, "Pilgrimage Processions, Religious Sensibilities and Piety in the City of Acre in the Latin Kingdom of Jerusalem," Mirabilia, MedTrans ı o, no. 2 (2019): I 48-166.

52 For a brief treatment and bibliography, see Youmans, "Rituals of Mobility and Hospitality", $5 \mathrm{I}-52$.

53 On this and other various religious and liturgical practices held at Marienburg, see Jóźwiak and Trupinda, Organizacja, 496-516. Processions were also an integral part of the Hospitaller's life, such as the procession to the prayer of thanksgiving or the one led through the hospital on a nightly basis. Cf. Cartulaire général de l'ordre des hospitaliers de Saint Jean de Jérusalem I Ioo-I3IO, vol. 3, ed. Joseph Delaville Le Roulx (Paris: E. Leroux, I 899), 3396 \$9; Cartulaire général de l'ordre des hospitaliers de Saint Jean de Jérusalem II0o-1310, vol. 4, ed. Joseph Delaville Le Roulx (Paris: E. Leroux, 1906), $4549 \$ 4$; and Regesta regni Hierosolymitani (mxcvii-mccxci), ed. Reinhold Rohricht (Innsbruck: Libreria academica wagneriana, I 893), I 374a. Prescriptions for liturgical processions of the early Templars are found in a twelfth-century ordinary of the community of the Holy Sepulchre ( I I 53- I I 57, see: Vatican City, Biblioteca Apostolica Vaticana, Barberiniano lat. 659). On such liturgical practices taken up by both communities, see: Cristina Dondi, The Liturgy of the Canons Regular of the Holy Sepulchre of Jerusalem: A Study and a Catalogue of the Manuscript Sources (Turnhout: Brepols, 2004). 


\section{The 'Preußenreisen' and the Table of Honour}

In what was tantamount to an instance of a pronounced influence from the monastic and most especially courtly-noble spheres, the table of honour (mensa honoris, thisch der eren, table d'honneur) constituted a ritual act played out between members of the Teutonic Knights and secular knights or rulers in the renowned 'Preußenreisen, outlined and detailed by W. Paravicini. ${ }^{54}$ It was thus an act calling for participation with non-members of the order. ${ }^{55}$ In an act of hospitality and appreciation - and ostensibly of (at least temporary) incorporation - in relation to the secular participants who volunteered to join the ranks of the Teutonic Knights in various battles of the northern crusades, foreign knights received an invitation to dine with the brothers and partake in the table of honour. The celebratory event comprised a series of monastic and courtly-noble gestures and speech acts, including the ennoblement of knights, the lifting of familial banners associated with particular patron saints, the initiation of heralds, and the veneration of saints. The symbolic gesture provides ample opportunity for reflection upon Assmann's considerations regarding ritual as an expression of living memory, in particular visà-vis the reinforcement of collective identity and its communication to 'outsiders.'

Perhaps the most extensive account of the Ehrentisch as an event is provided by the French chronicler Jean Cabaret d'Orville, a dignitary in the court of Duke Louis of Bourbon, who travelled to the Baltic in the latter half of the fourteenth century. ${ }^{56}$ D'Orville's report tells of the Duke's sojourn at Marienburg where they convened with various nobles, above all the Grand Master, who received them as guests and showed them hospitality. Louis joined forces with the Teutonic Order and together they fought against the rulers of Lithuania and of Norgalles, con-

54 Paravicini, Die Preußenreisen, I: 3 1 6-334; id., Die Preußenreisen des europäischen Adels, vol. 2 (Sigmaringen: Thorbecke, 1995), I 22-1 37; see also: Albert S. Cook, "Beginning the Board in Prussia," The Journal of English and Germanic Philology i 4, no. 3 (I 9 I 5):375-388.

ss A further instance of a participatory act between the Teutonic Knights and outsiders was the Corpus Christi procession practiced by the order in Palermo as a means to establish a shared sense of identity between the Teutonic Knights and associated groups from the region under the umbrella of a Teutonic "family." On this, see: Kristjan Toomaspoeg, "L'abito non fa il monaco: il quesito delle 'confraternitates Sancte Marie Alamannorum,', in Analecta Theutonica. Studies for the History of the Teutonic Order, ed. id., Acta Theutonica Io (Galatina: M. Congedo, 2014), I 5 8- I 59; id., Les Teutoniques en Sicile (1197-1492) (Rome: Collection de l'École française de Rome, 2003), 379-380; and Antonino Giuffrida, "Il potere del segno. La transizione della Magione da baliato a commenda," in I Cavalieri Teutonici tra Sicilia e Mediterraneo. Atti del Convegno Internazionale (Agrigento, 24-25 marzo 2006), eds. Antonino Giuffrida, Hubert Houben, and Kristjan Toomaspoeg (Galatina: M. Congedo, 2007), I65-166.

s6 Jean Cabaret d'Orville, Chronique du bon duc Loys de Bourbon, ed. A. M. Chazaud (Paris: la Société de l'Histoire de France, I 876), 62-66. 
quering the castle of Enrach in a battle that lasted eight days. On the ninth day, the parties made a peace treaty with the caveat that neither was to destroy the other's sacred spaces. In celebration of their triumph, the victors were granted a seat at the table of honour. The Grand Master had a table prepared in the Marienburg fortress complex. He requested that twelve knights from different kingdoms be present for the feast. Each member of the table was to be recognised as a knight worthy of the highest esteem. Knights were served in order of the social rank accorded to them. Their level of importance also determined their placement in the seating arrangement. The feast reached its peak with a momentous occasion - a knight brother of the order granted each member a badge with the gold-inlaid inscription honneur vainc tout!, "honour conquers all." Yet it was not only the honour of the order that was celebrated (though it most certainly was), but also that of their allies and co-combatants. The act united the parties in an orchestrated celebration of mutual admiration and regard and symbolically aligns their principles and values.

Indeed, this central ritual act was of interest to members of the (especially lower) nobility, as participation in such events brought with it many benefits, not least of which the opportunity to be knighted and obtain indulgence for themselves as well as great honour (and in part spoils of war) for their family. It thus transpired that countless nobles and even renowned rulers of Europe engaged in armed combat alongside the order's knight brothers and were - in a sense - made honorary members of the order and brought prestige and high standing on their houses. With such symbolic acts, the Teutonic Order therefore not only employed a means of reinforcing and indeed communicating their cultural function and significance as knight-monks, but also of bolstering the noble pride of those who joined them in their struggle against the varied enemies of Christendom.

Analysis of the act in terms of its implication for the societal model of the noble knight constitutes a dimension of the act that is largely unexamined in the academic literature to date. The connotation is perhaps best encapsulated by a passage in Peter of Dusburg's Chronicon terrae Prussiae wherein the chronicle addresses the matter of nobility and how it is defined. ${ }^{57}$ Here, he sets forth a redefinition of noble standing with relevance to the present issue. The motif proposes instructions to the brothers when handling cases of Prussians, who had converted to the faith after the removal of their pagan belief in gods (Quicunque relicta ydolatria se transfert ad fidem Christi, fratres agunt cum eo misericorditer in hunc modum)..$^{8}$ The brothers were to treat them in the following way. If the convert was of noble birth, goods were to be freely transferred to him, and to the degree that he was of

57 Petrus de Dusburg, "Chronicon terrae Prussiae," ed. Toeppen, I 46 n. 220.

s8 Ibid. 
the appropriate rank, he could lead his life accordingly. If the convert was, however, not of noble standing, then he was to serve the brothers in accordance with the custom that previously had been practiced in Prussia, unless it should be done differently out of consideration for their earnings or debt. For instance, concerning the non-aristocrats who were loyal to the brothers at the time of apostasy or in other times of great need for faith, their special merits demanded that their non-aristocratic status be transformed into venerable nobility and their lack of freedom into well-deserved freedom. ${ }^{99}$ The chronicler alludes to many instances of converts who were not so faithful, claiming that there were many newly baptised people in Prussia, whose ancestors were of noble origin; yet they themselves were classified as non-nobles because of the wickedness they exercised against the faith and against Christians. Others, however, whose ancestors were non-noble, were granted freedom because of their loyalty to the faith and to the brothers. The passage thus makes an equivocation between noble status and moral conduct or ethical merit, regardless of one's ancestry. Interestingly, alignment with the order and loyalty to their cause appear to be the principal criteria of this moral conduct that they so laud. The passage avows a radical departure from the traditional sense of nobility, wherein noble status was based largely on one's bloodline being of noble origin, which was consequently shown and confirmed in trappings and conduct fitting of a person of aristocratic descent. As a result, with the given passage the chronicler prepares his audience to enter into a spirit of openness concerning the strictest sense of noble status and its ability to be coalesced with motifs from monasticism and crusading rhetoric.

Similarly, the brothers' practice of the Ehrentisch as ritual connoted a redefinition or sublimation of nobility. The order and its knightly allies partook in a ritual act resembling a peculiar amalgam of courtly feast, pilgrimage, crusade, hunting campaign, and tournament $-{ }^{60}$ some of these activities typical of noble courts were officially forbidden the knight brothers, for instance hunting, tournaments, and

s9 Ibid. [...] verbi gracia ignobiles, qui in apostasia seu aliis necessitatibus fidei fratribus fideliter adheserunt, nunquam preclara ipsorum merita hoc exigunt, quod ignobilitas eorum in nobilitatem transeat generosam, et servitus in debitam libertatem? Utique, Domine. Et sane hec intelligas e converso. Unde multi sunt neophiti in terra Prussie, quorum progenitores fuerunt de nobili prosapia exorti, ipsi vero propter suam maliciam, quam contra fidem et Cristifideles exercuerunt, ignobiles estimati sunt $[\ldots]$.

60 On the societal function and significance of such activities, see Das ritterliche Turnier im Mittelalter: Beiträge zu einer vergleichenden Formen- und Verhaltensgeschichte des Rittertums, ed. Josef Fleckenstein (Göttingen: Vandenhoeck \& Ruprecht, I985); Jagd und höfische Kultur im Mittelalter, ed. Werner Rösener (Göttingen: Vandenhoeck \& Ruprecht, I 997); Leben am Hof: Königs- und Fürstenhöfe im Mittelalter, ed. Werner Rösener (Ostfildern: Thorbecke 2008), 216-220. 
games of chance, although their secular counterparts certainly participated during their time at and around Königsberg. ${ }^{61}$ The act served, however, more importantly not only to enhance the pride and self-image regarding the nobility and of the order, but also to generate a sublimation of the model of the chivalrous knight and a realignment of core values with those of the order as defenders of the faith unto the glory of God. Its symbolic function was to channel and transform noble dignity and self-importance into the order's image as the new Maccabees ${ }^{62}$ divinely commissioned to protect and defend the faith. The order's 'cultural memory' - to speak in Assmann's terms - was thus animated, lived out, and communicated in this and other symbolic gestures for the order's members and for the outside world to behold and indeed partake in.

\section{Conclusion}

In summation, we have seen that rituals are able not only to commemorate, but also to embody and render present a compact expression of institutional identity, or in the terminology and meaning of J. Assmann, living cultural memory. Each ritual act held to and conducted by a collective is an embodiment and a re-affirmation of a collective identity in its disembodied form. It unites the ritual agents in - and transforms into - living memory, in that it renders concrete an institutional arrangement in an incarnate, orchestrated symbolic form. Such phenomena are manifestly evident in the communal life of the Teutonic Knights and sustain their organisation qua institution as a self-perpetuating mechanism of cultural expression. Choice examples have been selected in order to present a representative backdrop for the landscape of assorted symbolic gestures envisioned and practiced by the order's members. The chosen instances reflect the diverse potential of the order to enact living memory in internal, public, and participatory settings, thereby evincing the various situational dynamics implied by exclusivity and inclusivity, the private and the public.

The order's rite of induction internally engrossed the ritual agents - with particular accent upon the initiated member - in the collective reality of their role as chivalrous and charitable knights in particular in view of notions aligned with the code of noble chivalry and with the monastic principles of hospitality. The communal admission and embracing of a new member occasioned a collective recall

61 Paravicini, Die Preußenreisen, i: 296-304.

62 This was an image most likely popularised (if not originated) by Peter Dusburg. See: Petrus de Dusburg, "Chronicon terrae Prussiae," ed. Toeppen, 25-29 n. I. 
lived out in word and deed, which invoked those present to actively render present their religious and chivalric vocation. The journey to and solemn procession at Marienburg (complete with reliquary exposition and almsgiving) carried out an expressly public means of reiterating the Teutonic Order's identity in terms of its dual estate and corresponding spheres of activity as well as the original mission to engage in crusading in the Holy Land. Here, emphasis on the order's role not only as white martyrs or monks, but as red martyrs can be insinuated. Finally, the table of honour had members of the order allied with secular knights and nobles in act and principle in a manner that surpassed and transcended classical ideals of nobility and united all participants under the order's core values.

With such symbolic gestures, the Teutonic Knights therefore not only sought to maintain and communicate their collective identity as cultural memory in accordance with both monastic and courtly-noble models, but they also effected an enhancement of noble pride and a sublimation of the societal model of the noble knight. It is conceivable that such identity-solidifying symbolic acts of the military orders, which referred to overarching ideals of both the religious and noble-knightly states, have played a special role in preserving their legitimacy, in particular after the fall of Acre I 29 I and the perceived failure of the crusade movements. Perhaps this too was a function of their ritual acts and their capacity to preserve and stabilise.

\section{PRIMARY SOURCES:}

Vatican City, Biblioteca Apostolica Vaticana, Barberiniano, lat. 659.

Das Ausgabebuch des Marienburger Hauskomturs für die Jahre I4IO-I42O. Edited by Walther Ziesemer. Königsberg: Thomas \& Oppermann, I 9 I I .

Cartulaire général de lordre des hospitaliers de Saint Jean de Jérusalem IIoo-I3Io. Vol. 3. Edited by Joseph Delaville Le Roulx. Paris: E. Leroux, I 899.

Cartulaire général de l'ordre des hospitaliers de Saint Jean de Jérusalem IIoo-I3Io. Vol. 4. Edited by Joseph Delaville Le Roulx. Paris: E. Leroux, 1906.

Chavasse, Antoine. Le sacramentaire gélasien (Vaticanus Reginensis ${ }_{3}$ I6): sacramentaire presbytéral en usage dans les titres romains au VIIe siècle. Tournai: Desclée, 1957.

Gnadenbrief für die S. Lorenz-Kapelle in der Marienburg. In Johannes Voigt, Geschichte Marienburgs, der Stadt und des Haupthauses des deutschen Ritter-Ordens in Preußen, 586-587. Königsberg: Gebrüder Bornträger, I 824 (Source edition No. VII).

"Di Kronike von Pruzinlant des Nikolaus von Jeroschin". Edited by Ernst Strehlke. In Scriptores rerum Prussicarum, vol. I, edited by Theodor Hirsch, Max Toeppen, and Ernst Strehlke, 29 I-624. Leipzig: S. Hirzel, i 86 I. 
Orville, Jean Cabaret d'. Chronique du bon duc Loys de Bourbon. Edited by A. M. Chazaud. Paris: la Société de l'Histoire de France, i 876.

Das Marienburger Ämterbuch. Edited by Walther Ziesemer. Danzig: A. W. Kafemann, G.m.b.H, i 9 I 6.

Petrus de Dusburg. “Chronicon terrae Prussiae.” Edited by Max Toeppen. In Scriptores rerum Prussicarum, vol. I, edited by Theodor Hirsch, Max Toeppen, and Ernst Strehlke, 3-269. Leipzig: S. Hirzel, i 85 I.

Regesta regni Hierosolymitani (mxcvii-mccxci). Edited by Reinhold Rohricht. Innsbruck: Libreria academica wagneriana, I 893.

Die Statuten des Deutschen Ordens nach seinen ältesten Handschriften. Edited by Max Perlbach. Halle: Max Niemeyer, i 890.

\section{Secondary sources:}

Althoff, Gerd. Die Macht der Rituale: Symbolik und Herrschaft im Mittelalter. Darmstadt: WBG, 2013 , 2nd edition.

Althoff, Gerd. Spielregeln der Politik im Mittelalter. Kommunikation in Frieden und Fehde. Darmstadt: WBG, I 997.

Assmann, Jan. "Communicative and Cultural Memory." In Cultural Memory Studies. An International and Interdisciplinary Handbook, edited by Astrid Erll and Ansgar Nünning, I o9- I I 8. Berlin: De Gruyter, 20 г o.

Assmann, Jan. Moses the Egyptian: The Memory of Egypt in Western Monotheism. Cambridge, Ma.: Harvard UP, 1998.

Assmann, Jan, and John Czaplicka. "Collective Memory and Cultural Identity.” New German Critique 65, no. 2 (1995): I25-133 (originally published: In Kultur und Gedachtnis, edited by Jan Assmann and Tonio Holscher, 9-1 9. Frankfurt a. Main: Suhrkamp, i 988 ).

Aurell, Martin. Des chrétiens contre les croisades: (XII $-X I I I^{e}$ siècle). Paris: Fayard, $20 \mathrm{I} 3$.

Blaauw, Sible de. "Following the crosses: The processional cross and the typology of processions in medieval Rome." In Christian Feast and Festival: The Dynamics of Western Liturgy and Culture, edited by Paul Post, Gerard A. M. Rouwhorst, Louis van Tongeren, and A. Scheer, 319-343. Leuven: Peeters, 200 I.

Bumke, Joachim. Höfische Kultur im hohen Mittelalter. München: Deutscher Taschenbuch Verlag, 2008, I 2 th edition.

Burgtorf, Jochen. The Central Convent of Hospitallers and Templars: History, Organization, and Personnel. (I0gg/II20-I3IO). Leiden-Boston: Brill, 2008.

Chollet, Loïc. "Croisade ou évangélisation? La polémique contre les Chevaliers Teutoniques à l'aune des témoignages des voyageurs français de la fin du Moyen Âge.” Ordines Militares Colloquia Torunensia Historica. Yearbook for the Study of the Military Orders 20 (2015): 175-203.

Chollet, Loïc. "Les Voyages en Prusse vus de France: la perception de la croisade contre la Lituanie dans quelques sources francophones (fin $\mathrm{XIV}^{\mathrm{e}}$ - début $\mathrm{XV}^{\mathrm{e}}$ siècle)." Studia zDziejów Średniowiecza I 9 (201 5): 5 I-80. 
Cook, Albert S. "Beginning the Board in Prussia." The Journal of English and Germanic Philology I 4, no. 3 (1915): 375-388.

Dondi, Cristina. The Liturgy of the Canons Regular of the Holy Sepulchre of Jerusalem: A Study and a Catalogue of the Manuscript Sources. Turnhout: Brepols, 2004.

Feistner, Edith. Krieg im Visier: Bibelepik und Chronistik im Deutschen Orden als Modell korporativer Identitätsbildung. Berlin: De Gruyter, 2007.

Fischer, Mary. "Di himels rote": The Idea of Christian Chivalry in the Chronicles of the Teutonic Order. Göppingen: Kümmerle, I 991 .

Flanigan, C. Clifford. "The moving subject: Medieval liturgical processions in semiotic and cultural perspective." In Moving Subjects: Processional performance in the Middle Ages and the Renaissance, edited by Kathleen M. Ashley and Wim N. M. Hüsken, 35-5 I. Amsterdam-Atlanta, Ga: Rodopi, 200 I.

Fleckenstein, Josef. "Die Rechtfertigung der geistlichen Ritterorden nach der Schrift 'De laude novae militiae' Bernhards von Clairvaux." In Die geistlichen Ritterorden Europas, edited by Josef Fleckenstein and Manfred Hellmann, 9-22. Sigmaringen: Thorbecke Jan Verlag, I 980.

Giuffrida, Antonino. "Il potere del segno. La transizione della Magione da baliato a commenda." In I Cavalieri Teutonici tra Sicilia e Mediterraneo. Atti del Convegno Internazionale (Agrigento, 24-25 marzo 2006), edited by Antonino Giuffrida, Hubert Houben, and Kristjan Toomaspoeg, I 59-202. Galatina: M. Congedo, 2007.

Grenzen des Rituals: Wirkreichweiten - Geltungsbereiche - Forschungsperspektiven. Edited by Andreas Büttner, Andreas Schmidt, and Paul Töbelmann. Köln: De Gruyter, 20 I 4. Halbwachs, Maurice. La topographie légendaire des Évangiles en Terre sainte: étude de mémoire collective. Paris: Presses Univ. de France, I 941.

Herrmann, Christofer. "Der Hochmeisterpalast auf der Marienburg. Rekonstruktionsversuch der Raumfunktionen." In “Magister operis.” Beiträge zur mittelalterlichen Architektur Europas. Festgabe für Dethard von Winterfeld zum 7o. Geburtstag, edited by Gabriel Dette, Laura Heeg, and Klaus T. Weber, 26I-294. Regensburg: Schnell \& Steiner, 2008.

Herrmann, Christofer. "Die herrschaftlichen Wohnräume im Hochmeisterpalast der Marienburg (Malbork) - ein frühes Beispiel des Stubenappartements im Spätmittelalter.” INSITU. Zeitschrift für Architekturgeschichte 2 (20 I 7 ): 2 I I - 228.

Herrmann, Christofer. "Kloster - Burg - Residenz: Der Hochmeisterpalast auf der Marienburg im Kontext der Burgenarchitektur des Deutschen Ordens in Preußen." in Ritter, Verwalter und Repräsentanten - Priester und Seelsorger: Burgen, Residenzen und Kirchen des Deutschen Ordens, edited by Helmut Flachenecker, 37-57. Weimar: VDG, 2016.

Hiestand, Rudolf. "Gott will es!" - Will Gott es wirklich? Die Kreuzzugsidee in der Kritik ibrer Zeit. Stuttgart: Kohlhammer, 1998.

Höfische Repräsentation. Das Zeremoniell und die Zeichen. Edited by Hedda Ragotzky and Horst Wenzel. Tübingen: WBG, I990. 
Im Spannungsfeld von Recht und Ritual: Soziale Kommunikation in Mittelalter und Früher

Neuzeit. Edited by Heinz Duchhardt and Gert Melville. Köln: Böhlau, I 997.

Jagd und höfische Kultur im Mittelalter. Edited by Werner Rösener. Göttingen: Vandenhoeck \& Ruprecht, 1997.

James, William. Manuscript Essays and Notes. Cambridge, Mass.: Harvard University Press, 1988.

Jerouschek, Günter. “Ecclesia non sitit sanguinem." In Handwörterbuch zur deutschen Rechtsgeschichte. Vol. I, Aachen-Geistliche Bank, edited by Albrecht Cordes, I I74- I 1 76. Berlin: Erich Schmidt Verlag, 2008, 2nd edition.

Jóźwiak, Sławomir, and Janusz Trupinda. "Das Leben auf der Marienburg zur Zeit der Hochmeister (I309-1457) nach schriftlichen mittelalterlichen Quellen.” In Das Leben im Ordenshaus, edited by Juhan Kreem, 28-39. Weimar: VDG, 2019.

Jóźwiak, Sławomir, and Janusz Trupinda. "Miejsca wystawiania instrumentów notarialnych w przestrzeni zamku malborskiego w XIV i w pierwszej połowie XV wieku.” Zapiski Historyczne 77, no. 2 (201 2): 7-34.

Jóźwiak, Sławomir, and Janusz Trupinda. "Nazwy pomieszczeń zamku malborskiego $\mathrm{w}$ instrumentach notarialnych z końca XIV - pierwszej połowy XV wieku." Zapiski Historyczne 72, no. 4 (2007): 41-56.

Jóźwiak, Sławomir, and Janusz Trupinda. Organizacja życia na zamku krzyżackim w Malborku w czasach wielkich mistrzów (I309-1457). Malbork: Muzeum Zamkowe, 20 I I, 2nd edition.

Koziol, Geoffrey. The Politics of Memory and Identity in Carolingian Royal Diplomas: The West Frankish Kingdom (840-987). Turnhout: Brepols, 20 I 2.

Koziol, Geoffrey. Begging Pardon and Favor: Ritual and Political Order in Early Medieval France. Ithaca-London: Cornell University Press, 1992.

Kwiatkowski, Krzysztof. "Christ ist erstanden... and Christians win! Liturgy and the Sacralization of Armed Fight against Pagans as Determinants of the Identity of the Members of the Teutonic Order in Prussia." In Sacred Space in the State of the Teutonic Order in Prussia, edited by Jarosław Wenta, IoI-I 29. Torun: Wydawnictwo Naukowe Uniwersytetu Mikołaja Kopernika, 2013.

Leben am Hof: Königs- und Fürstenhöfe im Mittelalter. Edited by Werner Rösener. Ostfildern: Thorbecke, 2008.

Lotan, Shlomo. "Pilgrimage Processions, Religious Sensibilities and Piety in the City of Acre in the Latin Kingdom of Jerusalem." Mirabilia, MedTrans 10, no. 2 (2019): I 48 - I 66 .

Mattox, John Mark. Saint Augustine and the Theory of Just War. New York-London: Continuum, 2006.

Mazeika, Rasa J. "Violent Victims? Surprising Aspects of the Just War Theory in the Chronicle of Peter von Dusburg." In The Clash of Cultures on the Medieval Baltic Frontier, edited by Alan V. Murray, I 23-1 40. Farnham: Routledge, 2009.

Medialität der Prozession: Performanz ritueller Bewegung in Texten und Bildern der Vormoderne / Médialité de la procession: performance du mouvement rituel en textes et en 
images à l'époque pré-moderne. Edited by Katja Gvozdeva and Hans Rudolf Velten. Heidelberg: Universitätsverlag Winter GmbH, 20 I I.

Melville, Gert. "Der historische Moment, das Repertoire und die Symbolik. Resümierende Überlegungen zu Beiträgen über performatives Handeln.” In Die Perfomanz der Mächtigen. Rangordnung und Idoneität in höfischen Gesellschaften des späten Mittelalters, edited by Klaus Oschema, Cristina Andenna, Gert Melville, and Jörg Peltzer, 2 1 7-234. Ostfildern: Jan Thorbecke Verlag, 2015.

Militzer, Klaus. "Die Aufnahme von Ritterbrüdern in den Deutschen Orden. Ausbildungsstand und Aufnahmevoraussetzungen." In Klaus Militzer, Zentrale und Region: gesammelte Beiträge zur Geschichte des Deutschen Ordens in Preussen, Livland und im Deutschen Reich aus den Jahren Ig68 bis 2008, 45-54. Weimar: VDG, 20 I 5.

Militzer, Klaus. “Die Hospitaltätigkeit des Deutschen Ordens.” Klaus Militzer, Zentrale und Region: gesammelte Beiträge zur Geschichte des Deutschen Ordens in Preussen, Livland und im Deutschen Reich aus den Jahren Ig68 bis 2008, 63-76. Weimar: VDG, 2015.

Mentzel-Reuters, Arno. "Der Deutsche Orden als geistlicher Orden.” In “Cura animarum.” Seelsorge im Deutschordensland Preußen, edited by Stefan Samerski, I 5-43. Cologne: Böhlau, 2013.

Mnemosyne. Formen und Funktionen der kulturellen Erinnerung. Edited by Aleida Assmann and Dietrich Harth. Frankfurt/Main: Fischer-Taschenbuch-Verlag, I 993.

El nacimiento de la orden de Calatrava. Primeros tiempos de expansión (siglos XII y XIII). Actas del I Congreso Internacional de la Orden de Calatrava. Almagro, octubre 2008. Edited by Ángela Madrid y Medina and Luis Rafael Villegas Díaz. Ciudad Real: Instituto de Estudios Manchegos, 2009.

Neecke, Michael. Literarische Strategien narrativer Identitätsbildung: eine Untersuchung der frühen Chroniken des Deutschen Ordens. Frankfurt: Peter Lang, 2008.

Oexle, Otto G. "Die funktionale Dreiteilung als Deutungsschema der sozialen Wirklichkeit in der ständischen Gesellschaft des Mittelalters.” In Ständische Gesellschaft und soziale Mobilität, edited by Winfried Schulze, I9-5 I. Munich: De Gruyter, I 988.

Oexle, Otto G. “'Die Statik ist ein Grundzug des mittelalterlichen Bewusstseins.' Die Wahrnehmung sozialen Wandels im Denken des Mittelalters und das Problem ihrer Deutung." In Sozialer Wandel im Mittelalter. Wahrnehmungsformen, Erklärungsmuster, Regelungsmechanismen, edited by Jürgen Miethke and Klaus Schreiner, 45-70. Sigmaringen: Jan Thorbecke Verlag, I 994.

Olick, Jeffrey K. "From Collective Memory to the Sociology of Mnemonic Practices and Products." In A Companion to Cultural Memory Studies, edited by Astrid Erll, I 5 I- I62. Berlin: De Gruyter, 20 io.

Olick, Jeffrey K. "Collective Memory: The Two Cultures." Sociological Theory 1 7, no. 3 (1999): 333-348.

Ordnung und Distinktion - Praktiken sozialer Repräsentation in der ständischen Gesellschaft. Edited by Marian Füssel and Thomas Weller. Münster: Rhema, 2005. 
Paravicini, Werner. Die ritterlich-höfische Kultur des Mittelalters. München: De Gruyter Oldenbourg, 1998.

Paravicini, Werner. Die Preußenreisen des europäischen Adels. Vol. I. Sigmaringen: Thorbecke, 1989 .

Paravicini, Werner. Die Preußenreisen des europäischen Adels. Vol. 2. Sigmaringen: Thorbecke, I995.

Die Perfomanz der Mächtigen. Rangordnung und Idoneität in höfischen Gesellschaften des späten Mittelalters. Edited by Klaus Oschema, Cristina Andenna, Gert Melville, and Jörg Peltzer. Ostfildern: Jan Thorbecke Verlag, 20 i 5.

Pospieszny, Kazimierz. Domus Malbork. Zamek krzyżacki w typie regularnym. Toruń: Wydawnictwo Uniwersytetu Mikołaja Kopernika, 20 I 4.

Pospieszny, Kazimierz. "Orte der Reliquienpräsentation in den Deutschordensburgen in Preußen: ein Beitrag zu neueren Forschungen." In "Ecclesiae ornatae." Kirchenausstattungen des Mittelalters und der frühen Neuzeit zwischen Denkmalwert und Funktionalität, edited by Gerhard Eimer, Ernst Gierlich, and Matthias Müller, 3 I I -326. Bonn: Kulturstiftung d. dt. Vertriebenen, 2009.

Prozessionen und ihre Gesänge in der mittelalterlichen Stadt: Gestalt - Hermeneutik Repräsentation. Edited by Harald G. Buchinger, David Hiley, and Sabine Reichert. Stuttgart: Schnell \& Steiner, 20 I 7.

Reynolds, Roger E. "The drama of medieval liturgical procession.” Revue de musicologie 86 (2000): I 27-I 42.

Riten, Gesten, Zeremonien: Gesellschaftliche Symbolik in Mittelalter und Früher Neuzeit. Edited by Edgar Bierende, Sven Bretfeld, and Klaus Oschema. Berlin: De Gruyter, 2008.

Das ritterliche Turnier im Mittelalter: Beiträge zu einer vergleichenden Formen- und Verhaltensgeschichte des Rittertums. Edited by Josef Fleckenstein. Göttingen: Vandenhoeck \& Ruprecht, i 985.

Rossi Vairo, Giulia. "Originality and Adaptation: The Architecture of the Teutonic Order in Italy." In Archaeology and Architecture of the Military Orders: New Studies, edited by Mathias Piana and Christer Carlsson, I 93-2 I 8. Farnham: Ashgate, 20 I 4.

Schenk, Gerrit Jasper. Zeremoniell und Politik. Herrschereinzüge im spätmittelalterlichen Reich. Köln: Vandenbhoeck \& Ruprecht, 2003.

Schwenk, Bernd. Calatrava. Entstehung und Frühgeschichte eines spanischen Ritterordens zisterziensischer Observanz im I2. Jahrhundert. Münster: Aschendorff, I 992.

Siberry, Elizabeth. Criticism of Crusading: I095-I274. Oxford: Clarendon Press, I 985.

Die Spielregeln der Mächtigen: mittelalterliche Politik zwischen Gewohnheit und Konvention. Edited by Claudia Garnier and Hermann Kamp. Darmstadt: WBG, 20 I o.

Die Spiritualität der Ritterorden im Mittelalter. Edited by Zenon H. Nowak. Toruń: Wydawnictwo Uniwersytetu Mikołaja Kopernika, I 993.

Toomaspoeg, Kristjan. "L'abito non fa il monaco: il quesito delle 'confraternitates Sancte Marie Alamannorum'." In Analecta Theutonica. Studies for the History of the Teutonic 
Order, edited by Kristjan Toomaspoeg, I 5 I-I 59. Acta Theutonica, Io. Galatina: M. Congedo, 2014.

Toomaspoeg, Kristjan. "La spiritualité des ordres religieux-militaires du Moyen Âge: l'état de la recherche." In Cister e as ordens militares na idade média. Guerra, igreja e vida religiosa, edited by José Albuquerque Carreiras and Carlos de Ayala Martínez Cister, 23-45. Tomar: Associação portuguesa de Cister., 2015.

Toomaspoeg, Kristjan. Les Teutoniques en Sicile (II97-1492). Rome: Collection de l'École française de Rome, 2003.

Torbus, Tomasz. Zamki konwentualne państwa krzyżackiego w Prusach. Gdańsk: Historia i Współczesność, 20 I 4.

Volgger, Ewald. "Die Feier von Kreuzauffindung und Kreuzerhöhung. Ursprung, Verbreitung und Bedeutung unter besonderer Berücksichtigung als Hochfeste des Deutschen Ordens." In Beiträge zur Geschichte des Deutschen Ordens. Vol. I, edited by Udo Arnold, I-50. Marburg: Elwert, I 993.

Volgger, Ewald. "Entstehung, Aufbau, Mitgliedschaft und Hierarchie im Deutschen Orden unter Berücksichtigung des Gesamtphänomens der geistlichen Ritterorden.” In Die Regeln des Deutschen Ordens in Geschichte und Gegenwart, edited by Ewald Volgger, I I-34. Vienna: Deutschordens-Verlag, i 985.

Waldstein-Wartenberg, Berthold Graf. Die "Vasallen Christi." Kulturgeschichte des Johanniterordens im Mittelalter. Köln: Böhlau Verlag, I 988.

Weiss, Dieter J. "Spiritual life in the Teutonic order: a comparison between the commanderies of Franconia and Prussia." In La commanderie, institution des ordres militaires dans l'Occident médiéval, edited by Anthony Luttrell and Léon Pressouyre, I 59-174. Paris: Comité des Travaux historiques et scientifiques, $200 \mathrm{I}$.

Wüst, Marcus. Studien zum Selbstverständnis des Deutschen Ordens im Mittelalter. Weimar: VDG, 2013.

Youmans, Nicholas W. "Rituals of Mobility and Hospitality in the Teutonic Knights." East Central Europe 47 (2020): 39-66.

Youmans, Nicholas W. "Seelenheil und Ritterehre. Vorstellung eines Forschungsprojekts zur Identität des Deutschen Ordens im Spiegel seiner Symbolhandlungen.” In Der Deutsche Orden aufdem Konstanzer Konzil: Pläne - Strategien - Erwartungen, edited by Helmut Flachenecker, I 57-I 75. Weimar: VDG Verlag, 2020.

Zacharias, Rainer. “Die Marienburg als Wallfahrtsstätte.” In Burgen kirchlicher Bauherren, edited by Thomas Biller, 49-60. Munich: Dt. Kunstverl., 200 I.

Zacharias, Rainer. "Die Reliquienwallfahrt zur Hochmeisterresidenz Marienburg." Zeitschrift für die Geschichte und Altertumskunde Ermlands 50 (2002): I I-36.

Zeremoniell und Raum, Potsdam, 25. bis 27. September 1994. Edited by Werner Paravicini. Symposium der Residenzen-Kommission der Akademie der Wissenschaften in Göttingen 4 / Residenzenforschung 6. Sigmaringen: Thorbecke, I 997. 